\title{
EFFECT OF A NANODISPERSION SILICA COMPOSITE WITH POLYHEXAMETHYLENE GUANIDINE HYDROCHLORIDE ON IMMUNOLOGICAL INDICATORS AND INDICATORS OF OXIDATION AND ANTIOXIDANT HOMEOSTASIS IN RATS WITH THERMAL BURN
}

\author{
A. Doroshenko, N. Gorchakova, G. Zaychenko
}

\begin{abstract}
У всьому світі: майже 6 млн осіб щзорічно звертаються по медичну допомогу з приводу опікових ран. На сьогоднішній день основним методом місчевого лікування ран та опіків, в тому числі інфікованих, є використання лікарських засобів, щуо містять антисептики, антибіотики, сорбенти, а також їх сполучення.
\end{abstract}

Мета. Визначити вплив композиту нанодисперсного кремнезему з полігексаметиленгуанидіну гідрохлоридом на імунологічні показники та показники окислювально-антиоксидантного гомеостазу у крові та осередку ураження шурів з неінфікованим термічним опіком.

Матеріали і методи. Дослідження проводилося на 72 щурах, яким моделювали термічний опік II ступеня. Тварини були розподілені на 4 групи: інтактні, контроль, ліковані хлоргексидином, ліковані композитом нанодисперсного кремнезему з полігексаметиленгуанидіну гідрохлоридом. На 7-y, 14-y, 21-y та 28-y добу тварин виводили з експерименту та визначали імунологічні показники та показники окислювальноантиоксидантного гомеостазу у крові та шкірі в осередку ураження.

Результати. Термічна травма безпосередньо пов'язана з біохімічними змінами в організмі. Нами порівнювалися рівні проти- та прозапальних цичтокінів, маркерів вільнорадикального окислення - дієнового коньюгату (ДК), активних продуктів тіобарбітурової кислоти (ТБК-АП), активність каталази (Кат) та супероксидисмутази (СОД). Було доведено, щчо композит НДК+ПГМГ-ГХ проявляє значно більш виражений, порівняно з хлоргексидином, фармакологічний ефект щзодо зниження рівня прозапальних ичи-

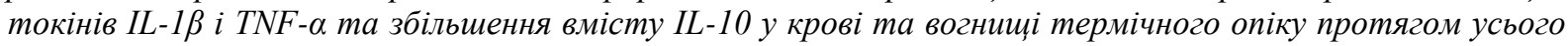
періоду спостереження. Також композит ефективно впливає на окиснювально-антиоксидантний гомеостаз, щчо виявляється нормалізацією вмісту ДК і ТБК-АП на 14-ту добу, відновленням активності Кат на 14-ту добу, СОД-вже на 7-му добу, порівняно з хлоргексидином.

Висновки. Проведене дослідження свідчить про те, щз композит НДК+ПГМГ-ГХ має виражені протизапальні та ранозагоювальні властивості, щзо дає змогу використовувати його як комбінований засіб для лікування термічних опіків

Ключові слова: термічний опік, композит нанодисперсного кремнезему з полігексаметиленгуанидіну гідрохлоридом, циттокіни, окислювально-антиоксидантний гомеостаз

Copyright (C) 2019, A. Doroshenko, N. Gorchakova, G. Zaychenko. This is an open access article under the CC BY license (http://creativecommons.org/licenses/by/4.0).

\section{Introduction}

Burn injuries affect the lives of millions of people around the world: nearly 6 million people seek medical care annually. In Ukraine, 80,000 of burnt annually register, $10 \%$ of which are children. For local burn treatment, it is advisable to use antibacterial agents that promote rapid wound healing while reducing the risk of infection [1].

To date, the main method of local treatment of wounds and burns, including those infected, is the use of drugs containing antiseptics, antibiotics, sorbents, as well as their combination.

However, as stated in the WHO report, "due to the lack of prompt and concerted action by many stakeholders, the world is entering an era when antibiotics are losing their effectiveness, and common infections and minor injuries that have been treated for decades can now be killed again". Particular attention was given to antibiotic resistance of $S$. aureus, $K$. pneumoniae, E. coli,
$P$. aeruginosa, which cause widespread serious illnesses, in particular sepsis, and play a leading role in the etiology of burn wounds. In some countries, the incidence of antibiotic resistance exceeds $50 \%$ [2].

Due to the increased resistance of microorganisms to some antibiotics, there are search for compounds that can be effective against them. One such compound is polyhexamethylene guanidine hydrochloride, which is used in most disinfectants in medicine and agriculture. In the form of hydrogels "Escalet" and "Biopag-D" polyhexamethylene guanidine hydrochloride is used in veterinary medicine to accelerate wound healing [3].

Polyhexamethylene guanidine hydrochloride has a broad spectrum of antimicrobial activity [4, 5], relatively low toxicity, high stability in the aquatic environment and in the earth $[6,7]$.

When comparing the antimicrobial action of polyhexamethylene guanidine with chlorhexidine diglu- 
conate, it was found that the polymer compound had a greater effect on multiresistant strains of microorganisms in a shorter time than chlorhexidine digluconate. These results substantiate the feasibility of including polyhexamethylene guanidine hydrochloride as the main (>70\%) in the composition of antiseptics and disinfectants for acting on antibiotic resistant strains [8-10].

Also for the treatment of burns, it is recommended to use sorbents, which contribute to the reduction of intoxication at various stages of burn disease and the quickest cleansing of wounds and their preparation for auto-dermoplasty. This is because the sorbents are able to capture hundreds of millions of microbial cells and their toxins on their surface and thus prevent the generalization of the infectious process.

Highly dispersed silica is characterized by high sorption capacity for proteins and microorganisms, a wide sorption spectrum. During its application, there are no toxic reactions, side effects and complications. Silicabased prolonged-release drugs provide for the gradual release of drugs (such as antibiotics) and their constant blood levels, reducing the daily dose, toxicity, and cost of treatment [11].

Therefore, to date, the development of a new complex drug for application sorption, which would affect the various parts of the wound, including burn, process and exhibit the properties of the sorbent, reparant, antimicrobial agent, becomes a very important task.

The Department of Pharmacology of the Bogomolets National Medical University and the Chuiko Institute of Surface Chemistry developed a composite of nanodispersed silica (NDS), a highly active sorbent, with PHMG having antimicrobial and wound healing properties.

The aim of our study was to determine the effect of nanosized silica composite with polyhexamethylene guanidine hydrochloride on the immunological and redox indices of blood and skin in lesions in rats with uninfected thermal burn.

During treatment, biochemical parameters of blood and skin in the lesion were determined, namely: the level of anti- and proinflammatory interleukins - IL$1 \beta$, TNF- $\alpha$, IL-10, as well as markers of free radical oxidation - diene conjugate (DC), thiobarbituric acid reactive substances (TBARS), catalase and superoxide dismutase activity.

\section{Planning (methodology) of research}

Thermal burn was modeled according to the recommendations of Yakovleva L. V. [12], under chloroform anesthesia. Therapy was performed with chlorhexidine ("Chlorhexidine-KR" - $0.05 \%$ solution for external use, PJSC "Chervona zirka", Ukraine) at doses specified in the instructions for use, adjusted by weight of experimental animals, as well as the NDS + PHMG composite in predetermined doses $(2000 \mathrm{mg} / \mathrm{kg}$ with a $20 \%$ content of PHMG). For the synthesis of the composite NDS + PHMG was used substance of highly dispersed silica of A-300 brand (LLC "Orisil-Kalush", Ukraine) and $20 \%$ solution of polyhexamethylene guanidine hydrochloride (PC "Termit").
Chlorhexidine was selected as the comparison drug because it has antimicrobial activity and is used as an antiseptic for the treatment of wounds and burns. The NDS + PHMG composite in the study is a combination agent that also has a broad spectrum of antimicrobial activity and additionally has pronounced antiinflammatory properties that we investigated in this experiment.

Since the aim of the study was to determine the level of cytokines, markers of free radical oxidation and activity of catalase and superoxide dismutase, which are the main antioxidant enzymes, the model that most met the task - to determine the anti-inflammatory and antioxidant activity of the studied compound. This model was characterized by a high level of inflammatory process, which is confirmed by an increase in the level of proinflammatory cytokines, a decrease in the level of antiinflammatory, as well as an increase in the content of markers of free radical oxidation and a decrease in the activity of antioxidant enzymes.

\section{Materials and methods}

The experiment was performed on 72 outbred white rats, which were divided into 4 groups: intact animals, control pathology group, animals treated with comparative drug chlorhexidine and animals treated with NDS + PHMG composite.

The animals of the experimental groups were simulated with a heated round metal plate on the lateral part of the thigh to model burns of the second degree. The next day after modeling in the chlorhexidine and NDS + PHMG groups, animals were treated and continued throughout the experiment (28 days). On the 7 th, 14 th, 21 st and 28th days, the animals were removed from the experiment and the biochemical parameters of blood and skin in the lesion were determined.

Work with laboratory animals was carried out in accordance with the provisions of the "European Convention for the Protection of Vertebrate Animals Used for Experimental and Other Purposes" (Strasbourg, 18.03.86) [13], EU Directive 609 of 24.11.1986 [14], Law of Ukraine "On the Protection of Animals from Cruelty" [15] and the Order of the Ministry of Education and Science of Ukraine of March 24, 2012 No. 249 "On approval of the procedure for conducting experiments, experiments on animals" by scientific institutions [16].

The arithmetic mean (M) and standard error of the mean $(\mathrm{m})$ were calculated on the basis of numerical values. After checking the normality of the distribution, the significance of the differences between the averages in the groups and in the dynamics from the Student's parametric t-test was determined. The Mann-Whitney U-test was used for comparative analysis of two independent samples from the variance of the abnormal distribution. Multiple comparisons were performed using ANOVA for normal distribution and the Kruskal-Wallis test by ranks for abnormal distribution. To test the significance of differences between the values of the variances for the data series, the Fisher test was used. The difference between the indicators was considered significant at the level of statistical significance over $95 \%$ (p <0.05) [17]. Statistical processing of data was performed using the 
computer software Statistics (Statsoft, USA) and Microsoft Office Excel (Microsoft Corp., USA).

\section{Results of the research}

In the control pathology group, the level of IL-1 $\beta$ in the serum was significantly increased during the entire observation period, its level was maximum by the 14th day (exceeded the intact control indicator by 2.2 times). By the 28th day its level gradually decreased, however, it did not normalize (was more by $22 \%$ in comparison with intact animals) (Table 1). A similar pattern was observed in the lesion - its level was higher than the indicator of intact control throughout the experiment (Table 2).

After use of chlorhexidine, IL-1 $\beta$ level was lower compared to the intact control group: on the 7th day - by $9 \%$, on the 14 th day - by $37 \%$, on the 21 st day - by $22 \%$, on the 28 th day - by $20 \%$ (Table 1 ). On the 7 th day after use chlorhexidine the content of IL-1 $\beta$ in the skin was not significantly different from the 2nd group, on the 14th day - the level of IL-1 $\beta$ decreased by $22 \%$, on the 21 st day - by $27 \%$, on the 28 th day - by $20 \%$ (Table 2).

Table 1

Effect of NDS + PHMG composite and chlorhexidine on the level of IL-1 $(\mathrm{PG} / \mathrm{ml})$ in serum of rats after thermal burn $(\mathrm{M} \pm \mathrm{m}, \mathrm{n}=6)$

\begin{tabular}{|c|c|c|c|c|}
\hline \multirow{2}{*}{ Group } & \multicolumn{4}{|c|}{ Terms of observation (days) } \\
\hline & 7 & 14 & 21 & 28 \\
\hline Intact & \multicolumn{4}{|c|}{$68.23 \pm 4.89$} \\
\hline Control & $126.16 \pm 6.06^{*}$ & $152.39 \pm 5.02 *$ & $105.62 \pm 4.32 *$ & $83.56 \pm 2.89 *$ \\
\hline Chlorhexidine & $114.78 \pm 5.67 * \#$ & $96.14 \pm 4.09 * \#$ & $82.59 \pm 2.57 * \#$ & $66.67 \pm 2.48 \#$ \\
\hline NDS+PHMG & $94.36 \pm 5.34 * \# \&$ & $78.89 \pm 2.75^{*} \# \&$ & $70.56 \pm 2.56 \# \&$ & $63.34 \pm 1.74 \# \&$ \\
\hline
\end{tabular}

Note: $* p<0.05$ - significance of differences compared to intact; \# $p<0.05$ - significance of differences compared to control; \& $p<0.05$ - significance of differences between NDS + PHMG composite versus chlorhexidine

The NDS + PHMG composite reduced the level of the concentration of IL-1 $\beta$ in the blood of rats to intact control by the 21 st day, in the cell - by the 28th day (Table 1 , 2 ). After use of the composite, there was a decrease in the content of IL-1 $\beta$ in serum and skin on the 7th, 14th, 21 st and 28th days compared with chlorhexidine (18\% and $13.5 \%$, $18 \%$ and $35 \%, 15 \%$ and $28 \%, 5 \%$ and $5 \%$ respectively). According to the results of the study in the control group, the content of TNF- $\alpha$ in the blood and hearth was higher compared to intact animals on the 7th day - 3.9 and 4.7 times, on the 14th day -3.7 and 2.8 times, and on the $21 \mathrm{st}$ day -3 and 2 times, on the 28th day - by $41 \%$ and $79 \%$, respectively (Table 3,4 ).

Chlorhexidine reduced the concentration of TNF$\alpha$ in the blood by 7 th, 14 th day.

On the 21 st and 28th days compared to the control by $42.5 \%, 52 \%, 52 \%$ and $32 \%$, and in the cell by $27.8 \%, 20.7 \%, 11 \%$ and $25.3 \%$ (Table 3, 4).

Table 2

Effect of NDS + PHMG composite and chlorhexidine on the level of IL-1 $\beta$ (PG / g protein) in the lesion in rats after thermal burn $(\mathrm{M} \pm \mathrm{m}, \mathrm{n}=6)$

\begin{tabular}{|c|c|c|c|c|}
\hline \multirow{2}{*}{ Group } & \multicolumn{4}{|c|}{ Terms of observation (days) } \\
\hline & 7 & 14 & 21 & 28 \\
\hline Intact & \multicolumn{4}{|c|}{$34.23 \pm 3.89$} \\
\hline Control & $78.45 \pm 3.95 *$ & $89.56 \pm 5.19 *$ & $76.88 \pm 3.21 *$ & $41.45 \pm 2.24 *$ \\
\hline Chlorhexidine & $80.18 \pm 3.19^{*}$ & $69.88 \pm 2.56^{*} \#$ & $55.78 \pm 2.34 * \#$ & $36.55 \pm 2.02 \#$ \\
\hline NDS+PHMG & $69.33 \pm 2.38 * \# \&$ & $45.28 \pm 3.13^{*} \# \&$ & $39.89 \pm 2.39 * \# \&$ & $34.30 \pm 1.85 \# \&$ \\
\hline
\end{tabular}

Note: $* p<0.05$ - significance of differences compared to intact; \# $p<0.05$ - significance of differences compared to control; \& $p<0.05$ - significance of differences between NDS + PHMG composite versus chlorhexidine

Table 3

Effect of NDS + PHMG composite and chlorhexidine on TNF- $\alpha$ level (PG / ml) in serum of rats after thermal burn $(\mathrm{M} \pm \mathrm{m}, \mathrm{n}=6)$

\begin{tabular}{|l|c|c|c|c|}
\hline \multirow{2}{*}{ Group } & \multicolumn{4}{|c|}{ Terms of observation (days) } \\
\cline { 2 - 5 } & 7 & 14 & 21 & 28 \\
\hline Intact & \multicolumn{4}{|c|}{$26.31 \pm 5.19$} \\
\hline Control & $104.49 \pm 13.91^{*}$ & $98.13 \pm 11.58^{*}$ & $79.62 \pm 8.47^{*}$ & $44.93 \pm 5.11^{*}$ \\
\hline Chlorhexidine & $60.07 \pm 2.58^{*} \#$ & $47.24 \pm 2.63^{*} \#$ & $38.02 \pm 1.75^{*} \#$ & $30.49 \pm 2.23 \#$ \\
\hline NDS+PHMG & $47.58 \pm 2.54 * \# \&$ & $39.21 \pm 2.23 * \# \&$ & $28.73 \pm 2.31 * \# \&$ & $22.45 \pm 0.69 \# \&$ \\
\hline
\end{tabular}

Note: $* p<0.05$ - significance of differences compared to intact; \# $p<0.05$ - significance of differences compared to control; \& $p<0.05$ - significance of differences between NDS + PHMG composite versus chlorhexidine 
Table 4

Effect of NDS + PHMG composite and chlorhexidine on TNF- $\alpha$ (PG / g protein) level in the lesion in rats after thermal burn $(\mathrm{M} \pm \mathrm{m}, \mathrm{n}=6)$

\begin{tabular}{|l|c|c|c|c|}
\hline \multirow{2}{*}{ Group } & \multicolumn{4}{|c|}{ Terms of observation (days) } \\
\cline { 2 - 5 } & 7 & 14 & 21 & 28 \\
\hline Intact & \multicolumn{4}{|c|}{$4.32 \pm 0.45$} \\
\hline Control & $20.32 \pm 2.08^{*}$ & $12.34 \pm 1.38^{*}$ & $8.69 \pm 0.49^{*}$ & $7.74 \pm 0.27^{*}$ \\
\hline Chlorhexidine & $14.67 \pm 1.32^{*} \#$ & $9.78 \pm 0.32^{*} \#$ & $7.73 \pm 0.46^{*} \#$ & $5.78 \pm 0.62^{*} \#$ \\
\hline NDS+PHMG & $8.46 \pm 0.83^{*} \# \&$ & $7.21 \pm 0.41^{*} \# \&$ & $5.32 \pm 0.18^{*} \# \&$ & $4.45 \pm 0.32 \# \&$ \\
\hline
\end{tabular}

Note: $*-p<0.05$ - significance of differences compared to intact; \# $p<0.05$ - significance of differences compared to control; \& $p<0.05$ - significance of differences between NDS + PHMG composite versus chlorhexidine

The use of the NDS + PHMG composite proved to be the most effective; it was found that the composite significantly reduced the serum $\mathrm{TNF}-\alpha$ content and lesion compared to chlorhexidine - on the 7 th day - by $20.7 \%$ and $42 \%$, on the 14 th day - by $17 \%$ and $26 \%$, by the 21 st day - by $24 \%$ and $31 \%$, by the 28 th day by $26 \%$ and $23 \%$, respectively. The NDS + PHMG composite normalized TNF- $\alpha$ level both in serum and in the cell until the 28th day (Tab. 3, 4).

We have shown that in case of burns there is a rapid decline of IL-10 levels in serum and lesions.
Throughout the observation period, there was a gradual increase, but not recovery. The concentration of IL-10 in the blood of rats of the control group was significantly lower than the indicators of the intact control group on the 7 th day - by $52.6 \%$, on the 14 th day - by $37 \%$, on the 21 st day - by $23 \%$ and did not normalize even to the 28th day (compared to intact animals, the level of IL-10 was reduced by $15 \%$ ) (Table 5 ). In the control group, lesions in the IL-10 level were less by the 7 th day - by $50 \%$, by the 14 th day - by $27 \%$, by the 21 st day - by $15.5 \%$, by the 28 th day - by $9.8 \%$ (Table 6 ).

Table 5

Effect of NDS + PHMG composite and chlorhexidine on IL-10 (pg / ml) level in rats serum during thermal burn $(\mathrm{M} \pm \mathrm{m}, \mathrm{n}=6)$

\begin{tabular}{|l|c|c|c|c|}
\hline \multirow{2}{*}{ Group } & \multicolumn{4}{|c|}{ Terms of observation (days) } \\
\cline { 2 - 5 } & 7 & 14 & 21 & 28 \\
\hline Intact & \multicolumn{4}{|c|}{$53.42 \pm 2.34$} \\
\hline Control & $25.32 \pm 1.85^{*}$ & $33.41 \pm 4.33^{*}$ & $41.23 \pm 3.18^{*}$ & $45.42 \pm 2.73^{*}$ \\
\hline Chlorhexidine & $24.61 \pm 2.82^{*}$ & $34.67 \pm 2.72 \#$ & $45.21 \pm 3.46^{*} \#$ & $52.01 \pm 2.41 \#$ \\
\hline NDS+PHMG & $33.41 \pm 1.64 * \# \&$ & $38.83 \pm 1.89^{*} \# \&$ & $47.21 \pm 1.62^{*} \# \&$ & $52.00 \pm 2.43 \#$ \\
\hline
\end{tabular}

Note: * p<0.05 - significance of differences compared to intact; \# $p<0.05$ - significance of differences compared to control; \& $p<0.05$ - significance of differences between NDS + PHMG composite versus chlorhexidine

Table 6

Effect of NDS + PHMG composite and chlorhexidine on the level of IL-10 (PG / g protein) in the lesion in rats after thermal burn $(\mathrm{M} \pm \mathrm{m}, \mathrm{n}=6)$

\begin{tabular}{|l|c|c|c|c|}
\hline \multirow{2}{*}{ Group } & \multicolumn{4}{|c|}{ Terms of observation (days) } \\
\cline { 2 - 5 } & 7 & 14 & 21 & 28 \\
\hline Intact & \multicolumn{4}{|c|}{$22.41 \pm 1.85$} \\
\hline Control & $11.12 \pm 1.34^{*}$ & $16.38 \pm 1.21^{*}$ & $18.92 \pm 2.47$ & $20.21 \pm 1.96$ \\
\hline Chlorhexidine & $12.64 \pm 1.44^{*}$ & $17.45 \pm 1.32^{*}$ & $19.14 \pm 3.09^{*}$ & $21.98 \pm 3.45^{*}$ \\
\hline NDS+PHMG & $15.87 \pm 1.54^{*}$ & $18.46 \pm 1.32^{*}$ & $20.78 \pm 2.32$ & $22.54 \pm 1.78$ \\
\hline
\end{tabular}

Note: $* p<0.05$ - significance of differences compared to intact; \# $p<0.05$ - significance of differences compared to control; \& $p<0.05$ - significance of differences between NDS + PHMG composite versus chlorhexidine

Level of IL-10 on the 7th day in blood and skin under the influence of chlorhexidine remained virtually unchanged compared to the intact control group (53\% and $44 \%$, respectively, lower than normal). On the 14th day the concentration of IL-10 in blood and skin was higher when using chlorhexidine compared to the control by only $3.7 \%$ and $6.5 \%$, respectively. At day 21 , the level of IL-10 in the blood was slightly higher when using chlorhexidine compared to the control by $9.6 \%$, in the skin was not significantly different. On day 28 , chlorhexidine normalized the content of IL-10 in the blood and skin of rats undergoing burns. The comparison drug increased the concentration of IL-10 in the blood by $14.5 \%$ relative to control; when using chlorhexidine in the skin the indicator was not significantly different from the group without treatment (Table 5, 6).

The most pronounced effect on the content of IL10 in the blood and lesion had the composite NDS + PHMG. The use of the test composite resulted in a faster and significantly increased level of IL-10 in the blood and skin compared to the control throughout the study (Table 5, 6). Under the influence of the composite NDS + PHMG on the 7th, 14th and 21st days, the concentration of IL-10 in the blood was higher compared to chlorhexidine - by $36 \%, 12 \%$ and $4 \%$, respectively. At day 28 after use of the composite, the level of IL-10 in the blood of rats was not significantly different from the level of IL-10 in the group of the comparator. When 
using the composite NDS + PHMG level of IL-10 in the cell increased already on the 7 th day compared with chlorhexidine - by $25.5 \%$.

In rats with thermal burn there was activation of free radical processes in the lesion occurred during the whole period of the experiment (Table 7,8 ). There has been an intensification of the process of lipid peroxidation (LPO) and the increase of its primary - diene conjugate (DC) and secondary products - thiobarbituric acid reactive substances (TBARS).

The content of DC and TBARS exceeded the norm by $7 \%$ on the 7 th day by $78 \%$ and $66 \%$, on the 14th day by $61 \%$ and $79 \%$, on the 21 st day by $42.5 \%$ and $42 \%$, on the 28th day by $36 \%$ and $27.2 \%$ respectively. Both studied indicators in this group did not normalize even on the 28 th day.
Chlorhexidine reduced the content of DC and TBARS in the lesion compared with control on the 7th day by $20 \%$ and $13.1 \%$, on the 14 th day - by $19 \%$ and $23.3 \%$, on the 21 st day - by $14 \%$ and $12,8 \%$, on the 28th day - by $17 \%$ decreased the level of DC, the values of the level of TBARS did not differ significantly compared with the control (Table 7, 8).

The use of NDS + PHMG composite proved to be much more effective, since the composite normalized the content of DC and TBARS in the skin of animals as early as the 14th day. The level of DC and TBARS decreased compared to the level of DC in the group chlorhexidine on the 7th day - by $13.6 \%$ and $11.9 \%$, on the 14 th day - by $13 \%$ and $13.5 \%$, on the 21 st day - by $12.9 \%$ and $9 \%$, on the 28th day - by $11.2 \%$ and $14.5 \%$, respectively (Table 7,8 ).

Table 7

Effect of NDS + PHMG composite and chlorhexidine on the level of DC ( $\mu \mathrm{mol} / \mathrm{g})$ in the lesion in rats after thermal burn $(\mathrm{M} \pm \mathrm{m}, \mathrm{n}=6)$

\begin{tabular}{|l|c|c|c|c|}
\hline \multirow{2}{*}{ Group } & \multicolumn{4}{|c|}{ Terms of observation (days) } \\
\cline { 2 - 5 } & 7 & 14 & 21 & 28 \\
\hline Intact & \multicolumn{4}{|c|}{$14.12 \pm 2.18$} \\
\hline Control & $25.24 \pm 1.11^{*}$ & $22.78 \pm 1.45^{*}$ & $20.12 \pm 1.86^{*}$ & $19.21 \pm 1.13^{*}$ \\
\hline Chlorhexidine & $20.21 \pm 1.46^{*} \#$ & $18.43 \pm 2.11^{*} \#$ & $17.29 \pm 1.12^{*} \#$ & $15.97 \pm 1.42 \#$ \\
\hline NDS+PHMG & $17.46 \pm 2.34^{*} \# \&$ & $16.02 \pm 2.13 \#$ & $15.06 \pm 1.36 \#$ & $14.18 \pm 1.13 \#$ \\
\hline
\end{tabular}

Note: $* p<0.05$ - significance of differences compared to intact; \# $p<0.05$ - significance of differences compared to control; $\& p<0.05$ - significance of differences between NDS + PHMG composite versus chlorhexidine

Table 8

Effect of NDS + PHMG composite and chlorhexidine on TBARS content (nmol /g) in the lesion in rats after thermal burn $(\mathrm{M} \pm \mathrm{m}, \mathrm{n}=6)$

\begin{tabular}{|l|c|c|c|c|}
\hline \multirow{2}{*}{ Group } & \multicolumn{4}{|c|}{ Terms of observation (days) } \\
\cline { 2 - 5 } & 7 & 14 & 21 & 28 \\
\hline Intact & \multicolumn{4}{|c|}{$5.01 \pm 0.35$} \\
\hline Control & $8.32 \pm 0.45^{*}$ & $8.98 \pm 0.12^{*}$ & $7.11 \pm 0.56^{*}$ & $6.89 \pm 0.71^{*}$ \\
\hline Chlorhexidine & $7.23 \pm 0.21^{*} \#$ & $6.89 \pm 0.32^{*} \#$ & $6.20 \pm 0.06^{*} \#$ & $5.94 \pm 0.43^{*}$ \\
\hline NDS+PHMG & $6.37 \pm 0.34^{*} \#$ & $5.96 \pm 0.41^{*} \# \&$ & $5.64 \pm 0.23^{*} \# \&$ & $5.08 \pm 0.13 \# \&$ \\
\hline
\end{tabular}

Note: $* p<0.05$ - significance of differences compared to intact; \# $p<0.05$ - significance of differences compared to control; $\& p<0.05$ - significance of differences between NDS + PHMG composite versus chlorhexidine

A concurrent study of the antioxidant system in the respective animal groups found that in rats with thermal burns, the activity of the antioxidant enzymes in the skin was lower in comparison to intact animals. The activity of catalase (Cat) and superoxide dismutase (SOD) was not restored even until the 28th day of the experiment and decreased in comparison to intact animals on the 7 th day by $64 \%$ and $27.2 \%$, on the 14 th day by $50 \%$ and $24,3 \%$, on the 21 st day - by $26.5 \%$ and $14.7 \%$, on the 28 th day - by $14 \%$ and $17.1 \%$ respectively (Table 9, 10).

Compared to controls, chlorhexidine increased the level of Kat in the skin on the 7th, 14th, 21st and 28th days by $45.5 \%, 16.3 \%, 6 \%$ and $13.8 \%$, respectively. The normalization of Cat activity when using chlorhexidine was observed on the 28th day (Table 9).

Table 9

Effect of NDS + PHMG composite and chlorhexidine on Cat (conventional units) activity in the lesion in rats after thermal burn $(\mathrm{M} \pm \mathrm{m}, \mathrm{n}=6)$

\begin{tabular}{|l|c|c|c|c|}
\hline \multirow{2}{*}{ Group } & \multicolumn{4}{|c|}{ Terms of observation (days) } \\
\cline { 2 - 5 } & 7 & 14 & 21 & 28 \\
\hline Intact & \multicolumn{4}{|c|}{$4.03 \pm 0.09$} \\
\hline Control & $1.45 \pm 0.37^{*}$ & $2.02 \pm 0.32^{*}$ & $2.96 \pm 0.29 *$ & $3.47 \pm 0.41^{*}$ \\
\hline Chlorhexidine & $2.11 \pm 0.13^{*} \#$ & $2.35 \pm 0.15^{*}$ & $3.14 \pm 0.22 \#$ & $3.95 \pm 0.34 \#$ \\
\hline NDS+PHMG & $2.38 \pm 0.23^{*} \#$ & $3.63 \pm 0.31^{*} \# \&$ & $3.92 \pm 0.14 \# \&$ & $4.03 \pm 0.03 \#$ \\
\hline
\end{tabular}

Note: $* p<0.05$ - significance of differences compared to intact; \# $p<0.05$ - significance of differences compared to control; \& $p<0.05$ - significance of differences between NDS + PHMG composite versus chlorhexidine 
More pronounced effect of chlorhexidine had on the activity of SOD, normalizing its level in the lesion center of rats with burn wound on the 14th day (Table 10). Chlorhexidine increased SOD activity compared to the untreated group by $12.1 \%$ on the 14th day, by $14.7 \%$ on the 21 st day, and no significant differences were observed on the 28th day. The maximum activation of the antioxidant system was observed with the NDS +
PHMG composite - Cat activity was restored on the skin on the 14th, SOD on the 7th day. The use of the composite led to an increase in the activity of Cat compared with chlorhexidine on the 14 th day by $54.5 \%$ (Table 9 ).

Compared with chlorhexidine, SOD activity in the skin of rats with thermal burns increased by $11.4 \%$ (on the 14th day) when applied with the composite (Table 10).

Table 10

Effect of NDS + PHMG composite and chlorhexidine on SOD activity (conventional units) in the lesion in rats after thermal burn $(\mathrm{M} \pm \mathrm{m}, \mathrm{n}=6)$

\begin{tabular}{|l|c|c|c|c|}
\hline \multirow{2}{*}{ Group } & \multicolumn{4}{|c|}{ Terms of observation (days) } \\
\cline { 2 - 5 } & 7 & 14 & 21 & 28 \\
\hline Intact & \multicolumn{4}{|c|}{$4.56 \pm 0.63$} \\
\hline Control & $3.32 \pm 0.12^{*}$ & $3.45 \pm 0.17^{*}$ & $3.61 \pm 0.34$ & $3.78 \pm 0.26$ \\
\hline Chlorhexidine & $3.42 \pm 0.19^{*}$ & $3.87 \pm 0.33^{*}$ & $4.14 \pm 0.48$ & $4.61 \pm 0.43$ \\
\hline NDS+PHMG & $3.79 \pm 0.31 \#$ & $4.31 \pm 0.68 \#$ & $4.51 \pm 0.21 \#$ & $4.58 \pm 0.3 \#$ \\
\hline
\end{tabular}

Note: $* p<0.05$ - significance of differences compared to intact; \# $p<0.05$ - significance of differences compared to control; \& p<0.05 - significance of differences between NDS + PHMG composite versus chlorhexidine

\section{Discussion of the results}

The study showed that thermal burns have a violation on the oxidative-antioxidant homeostasis. Free radical oxidation processes are activated, which leads to intensification of lipid peroxidation processes and depletion of the antioxidant system. The NDS+PHMG composite effectively influenced the oxidation-antioxidant homeostasis indices, restoring them by the middle of the observation period, indicating its high antioxidant properties, which is provided by the nanodispersed silica. The NDS absorbs tissue breakdown products and removes them, accelerating wound repair.

The level of proinflammatory cytokines in the blood and lesion in untreated rats was higher than intact controls throughout the observation period, and IL-10 levels were reduced. After the use of chlorhexidine, the level of IL-1 $\beta$ and TNF- $\alpha$ both in the blood and in the lesion decreased almost to normal and the level of IL-10 increased. The use of the NDS + PHMG composite led to more significant changes in these parameters, normalizing them, which also indicates the anti-inflammatory properties of the compound.

As the literature does not describe the effect of the NDS + PHMG composite on burn wound healing, immunological parameters, and oxidative antioxidant homeostasis, we can compare our findings with those of the composite components.

According to the literature, in the treatment of burn wounds in experimental animals, the polyhexymethylene guanidine hydrogel showed greater wound healing activity compared to the reference drug Levomecol, resulting in a greater reduction in wound surface area on the 10th day of treatment. Wound healing after application of polyhexamethylene guanidine was faster than in control animals treated with placebo (sodium chloride solution) locally. The drug increased the amount of antioxidants in the blood, normalized the content of leukocytes in the peripheral blood [18].

Similar results were also obtained with the use of polyhexamethylene guanidine in linear skin and muscle wounds. The drug normalized the number of leukocytes in the peripheral blood and had antioxidant activity [19].

In the case of nanosized silica alone, the epithelialization of the wound was observed in mice that were simulated with grade III-B infected burn for 24 days [20].

With the use of composite silica with metronidazole, the incidence of postoperative complications, such as suppuration of the surgical wound and suture differences decreased, and the healing time of purulent wounds of different localization was reduced. Moreover, the antimicrobial activity of metronidazole in the composite even increased compared to monodrugs due to the sorption of microorganisms [11].

Since microorganisms that colonizing the affected area play a significant role in the development of complications after thermal burns, it is important to use nonresistant antimicrobials. Therefore, the use of mechanical sorption in the face of increasing antibiotic resistance is extremely important. In the experiments, it was proved that highly dispersed silica is adsorbed on the surface of the microorganism and leads to their agglutination. In addition, highly dispersed silica neutralizes the adhesive properties of the bacterial cell, which impedes biofilm formation and subsequent wound infection [21].

Other authors also note significant antibacterial, wound healing and sorption properties of sorbents based on highly dispersed silica with antibacterial preparations immobilized on its surface for the treatment of purulent surgical wounds, abscesses and phlegmon of soft tissues in the complex treatment of purulent complications [22].

In addition, the use of complex composite of highly dispersed silica with levofloxacin on the model of infected thermal burn contributed to a faster normalization of lipid peroxidation and antioxidant system, which may testify to the powerful antioxidant, antiinflammatory and antimicrobial properties of experimental [23].

Analyzing the experimental and clinical results, we concluded that it is advisable to create a nanocomposite with the inclusion of an antimicrobial antioxidant 
polyhexamethylene guanidine and nanodispersed silica, which can enhance the antimicrobial properties of the polymer and reduce its toxicity. Nanosilica in the composite is able to provide lymphosanation and protect intact tissues from hypoxia, as well as to prevent absorption of polyhexamethylene guanidine, which will reduce the toxicity of the composite. Further in-depth studies of the anti-inflammatory, wound-healing and metabolic properties of the new nanodispersed silica composite with polyhexamethylene guanidine will provide new data on its mechanism of action and pharmacodynamics, and outline the prospects of its use for wound healing therapy.

Limitations of the study. Because the NDS + PHMG composite was applied in suspension and the wound area was not covered by a bandage to prevent loss of active components due to the interaction of animals with the environment, the therapeutic effect of the composite may be diminished.

A further limitation was that the study was performed on a model of uninfected thermal burn, while usually burns are accompanied by infection and the results of treatment may vary, including the time of normalization of immunological and oxidative-antioxidant homeostasis.

In addition, research is a stage of preclinical study of the effectiveness of a new composite on the burn wound model in rats, and it is impossible to accurately extrapolate the results to a similar thermal burn model in humans.

\section{Conclusions}

The NDS + PHMG composite exhibits a much more pronounced pharmacological effect, compared to chlorhexidine, in reducing the level of the proinflammatory cytokines IL- $1 \beta$ and TNF- $\alpha$ and increasing the IL-10 content in the blood and the site of thermal burn during the entire observation period. In addition, the composite effectively affects the oxidative-antioxidant homeostasis, which is manifested by the normalization of the content of DC and TBASP on the 14th day, restoration of Cat activity on the 14th day, SOD - on the 7th day, compared with chlorhexidine.

Composite NDS + PHMG effectively reduces the level of proinflammatory and increases the level of proinflammatory cytokines, indicating the presence of antiinflammatory properties, as well as antioxidant, since the composite also normalized the oxidative-antioxidant homeostasis by normalizing the content of markers of free radical oxidation and oxidation to accelerate the treatment of thermal burns.

The results lead to a more detailed study of the anti-inflammatory and antioxidant properties of the NDS + PHMG composite. However, based on the obtained results, it is possible to recommend a composite for the treatment of burn wounds and prevention of infectious complications.

\section{Conflict of interest}

There is no conflict of interest.

\section{References}

1. Vons, B. V., Chubka, M. B., Groshovyi, T. A. (2018). The problem of treatment of burns' wounds and characteristic of drugs for the local treatment of burns. Current issues in pharmacy and medicine: science and practice, 11 (1 (26)), 119-125. doi: http://doi.org/10.14739/2409-2932.2018.1.123731

2. Global action plan on antimicrobial resistance (2015). World Health Organization. Available at: https://www.who.int/antimicrobial-resistance/global-action-plan/en/

3. Grigorev, I. A., Polienko, Iu. F., Voinov, M. A. (2009). rN-CHuvstvitelnye nitroksilnye radikaly: strukturnye trebovaniia, problemy molekuliarnogo dizaina i sinteticheskie podkhody. Khimiia aromaticheskikh, geterociklicheskikh i prirodnykh soedinenii. Novosibirsk: ZAO IPP «Ofset», 501-535.

4. Walczak, M., Richert, A., Burkowska-But, A. (2014). The effect of polyhexamethylene guanidine hydrochloride (PHMG) derivatives introduced into polylactide (PLA) on the activity of bacterial enzymes. Journal of Industrial Microbiology \& Biotechnology, 41 (11), 1719-1724. doi: http://doi.org/10.1007/s10295-014-1505-5

5. Gendaszewska, D., Szuster, L., Wyrębska, Ł., Piotrowska, M. (2018). Antimicrobial Activity of Monolayer and Multilayer Films Containing Polyhexamethylene Guanidine Sulphanilate. Fibres and Textiles in Eastern Europe, 26 (2 (128)), 73-78. doi: http://doi.org/10.5604/01.3001.0011.5742

6. Lucas, A. D. (2011). Environmental Fate of Polyhexamethylene Biguanide. Bulletin of Environmental Contamination and Toxicology, 88 (3), 322-325. doi: http://doi.org/10.1007/s00128-011-0436-3

7. Lysytsya, A. V. (2017). Research on the impact of polyhexamethyleneguanidine on the plant component of biocenoses. Biosystems Diversity, 25 (2), 89-95. doi: http://doi.org/10.15421/011713

8. Zhou, Z., Wei, D., Lu, Y. (2014). Polyhexamethylene guanidine hydrochloride shows bactericidal advantages over chlorhexidine digluconate against ESKAPE bacteria. Biotechnology and Applied Biochemistry, 62 (2), 268-274. doi: http://doi.org/10.1002/bab.1255

9. Oule, M. K., Azinwi, R., Bernier, A.-M., Kablan, T., Maupertuis, A.-M., Mauler, S. et. al. (2008). Polyhexamethylene guanidine hydrochloride-based disinfectant: a novel tool to fight meticillin-resistant Staphylococcus aureus and nosocomial infections. Journal of Medical Microbiology, 57 (12), 1523-1528. doi: http://doi.org/10.1099/jmm.0.2008/003350-0

10. Gilbert, P., Moore, L. E. (2005). Cationic antiseptics: diversity of action under a common epithet. Journal of Applied Microbiology, 99 (4), 703-715. doi: http://doi.org/10.1111/j.1365-2672.2005.02664.x

11. Cherniakova, H. M., Minukhin, V. V., Voronin, Ye. P. (2016). Suchasnyi pohliad na mistseve likuvannia opikiv z infektsiinoiu skladovoiu. Visnyk problem biolohii i medytsyny, 1 (4), 68-72.

12. Yakovlieva, L. V., Tkachova, O. V., Butko, Ya. O., Larianovska, Yu. B. (2013). Eksperymentalne vyvchennia novykh preparativ dlia mistsevoho likuvannia ran. Kharkiv: Vyd-vo NFaU, 52.

13. Yevropeiska konventsiia pro zakhyst khrebetnykh tvaryn, shcho vykorystovuiutsia dlia doslidnytskykh abo inshykh naukovykh tsilei 18.03.1986 (1986). Verkhovna Rada Ukrainy. Mizhnarodni dokumenty (Rada Yevropy). Available at: https://zakon.rada.gov.ua/laws/show/994_137

14. Council Directive 86/609/EEC of 24 November 1986 on the Approximation of the Laws, Regulationsand Administrative Provisions of the Member States Regarding the Protection of Vertebrate Animals Used for Experimental and Other Scientific Purposes (1986). Official Journal of the European Communities, 358, 1-29. 
15. Pro zakhyst tvaryn vid zhorstokoho povodzhennia (2006). Zakon Ukrainy \# 3447-IV. Vidomosti Verkhovnoi Rady Ukrainy, 27, 230. 24,82 .

16. Poriadok provedennia naukovymy ustanovamy doslidiv, eksperymentiv na tvarynakh (2012). Ofitsiinyi visnyk Ukrainy,

17. Glanc, S. (1998). Mediko-biologicheskaia statistika. Moscow: Praktika, 459.

18. Lebedeva, S. N., Ochirov, O. S., Stelmakh, S. A., Grigoreva, M. N., Zhamsaranova, S. D., Mognonov, D. M. (2017). Wound healing effect of polyhexamethylene guanidine hydrochloride hydrogel at burns. Acta Biomedica Scientifica, 2 (4), $93-96$. doi: http://doi.org/10.12737/article_59fad51d481658.42549272

19. Lebedeva, S. N., Ochirov, O. S., Stelmakh, S. A., Grigor'eva, M. N., Zhamsaranova, S. D., Mognonov, D. M. (2018). Reparative action of hydrogel polygexamethylenuanidine hydrochloride. Bulletin of Siberian Medicine, 17 (1), 112-120. doi: http://doi.org/10.20538/1682-0363-2018-1-112-120

20. Beliaeva, O. A., Neshta, V. V., Prociuk, R. R., Tugushev A. S. (2007). Primenenie applikacionnykh sorbentov novogo pokoleniia $\mathrm{v}$ gnoinoi khirurgii. Klinichna khirurgiia, 11/12, 5-6.

21. Geraschenko, I. I. (2009). Membranotropnye svoistva nanorazmernogo kremnezema. Poverkhnost, 1 (16), 288-306.

22. Cherniakova, H. M., Minukhin, V. V., Voronin, Ye. P., Minukhin, D. V., Krasnoiaruzhskyi, A. H., Yefimov, D. S., Ponomarova, K. V. (2017). Obgruntuvannia antymikrobnoi efektyvnosti aplikatsiinykh bionanokompozytiv dlia likuvannia opikovoi infektsii, sprychynenoi S. aureus ta P. Aeruginosa. Klinichna khirurhiia, 12, 48-51.

23. Cherniakova, H. M., Minukhin, V. V., Horbach, T. V. (2017). Porivnialne doslidzhennia biokhimichnykh pokaznykiv myshei z opikovoiu Pseudomonas-infektsiieiu pry likuvanni novymy aplikatsiinymy sorbentamy. Eksperymentalna i klinichna medytsyna, 4, 15-21.

Received date 30.07.2019

Accepted date 20.08.2019

Published date 31.08.2019

Anna Doroshenko, Assistant, Department of Pharmacology, Bogomolets National Medical University, T. Shevchenko blvd., 13, Kyiv, Ukraine, 01601

E-mail: Annadoroshenko2015@gmail.com

Nadiya Gorchakova, MD, Professor, Department of Pharmacology, Bogomolets National Medical University, T. Shevchenko blvd., 13, Kyiv, Ukraine, 01601

Ganna Zaychenko, MD, Professor, Head of Department, Department of Pharmacology, Bogomolets National Medical University, T. Shevchenko blvd., 13, Kyiv, Ukraine, 01601 